Article

\title{
Vernacular Farm Buildings and Rural Landscape: A Geospatial Approach for Their Integrated Management
}

\author{
Giuseppe Cillis $₫$, Dina Statuto $₫$ and Pietro Picuno * * \\ SAFE School of Agricultural, Forest, Food and Environmental Sciences, University of Basilicata, Viale \\ dell'Ateneo Lucano, n. 10, 85100 Potenza, Italy; giuseppe.cillis@unibas.it (G.C.); dina.statuto@unibas.it (D.S.) \\ * Correspondence: pietro.picuno@unibas.it
}

Received: 12 November 2019; Accepted: 16 December 2019; Published: 18 December 2019

\begin{abstract}
Over the centuries, farm buildings, which accompany the development of agriculture, have played an important role in defining spatial and environmental planning. In some European countries in particular, these rural structures have been built based on traditional agricultural needs and typical land characteristics. Considering the land abandonment that has occurred over the last five decades, with farmers moving to more comfortable residences in neighboring urban settlements, historical farm buildings have often been abandoned, thus causing a leakage of the historical-cultural heritage of the rural landscape. Nowadays, open data and geographic technologies together with advanced technological tools allow us to gather multidisciplinary information about the specific characteristics of each farm building, thus improving our knowledge. This information can greatly support the protection of those buildings and landscapes that have high cultural and naturalistic value. In this paper, the potential of Geographic Information Systems to catalogue the farm buildings of the Basilicata region (Southern Italy) is explored. The analysis of these buildings, traditionally known as masserie, integrates some typical aspects of landscape studies, paving the way for sustainable management of the important cultural heritage represented by vernacular farm buildings and the rural landscape.
\end{abstract}

Keywords: vernacular farm buildings; rural landscape; geographical information system; cultural heritage; integrated management

\section{Introduction}

The concurrent process of land abandonment and soil degradation, which is afflicting several marginal areas in the world, is totally redesigning the shape and the functionality of rural areas, negatively influencing the traditional features of their landscape [1]. Human activities shape the land in relation to human needs. In particular, agricultural production has been the main driver for the characterization of the different historical rural landscapes, especially detectable in several Mediterranean regions [2]. However, the process of abandoning agricultural areas has led to a change from both an ecosystem and a landscape point of view, causing different impacts with different repercussions from country to country and from region to region. It is estimated that, in the future, this abandonment will affect more and more areas in Europe and throughout the world [3,4]. This process, which has taken place in the last 50 years, is now accelerating, especially in marginal and mountainous areas, due to multiple factors linked to worsening economic conditions and the steady migration of rural workers from small villages to large cities $[5,6]$. New approaches and methods are therefore needed on a large scale as well as on a small scale in order to adapt environmental planning techniques to different territorial, landscape, and socio-economic needs. 
The abandonment of agricultural activities concern the territorial aspects related to land use, land cover, and farm buildings, especially those having an historical importance, as well as those related to traditional agricultural activities [7].

These vernacular farm buildings built over the decades to play an important agricultural role now have high heritage value. Agricultural construction is truly a unique example in the construction sector [8], since the birth, the growth, and the development of animals and plants living in these buildings present specific architectural and technical needs very different from other construction sectors. Designed to produce perfect environmental conditions for plants and animals as well as the workers involved in day-to-day management, the rural building is a technological model of particular interest $[9,10]$. The role of the farm building is closely linked to the surrounding context due to the farmer's need to live in close contact with land and livestock; what happens inside the building reflects what happens in the surrounding environment [11-13].

Considering the need for farmers to live in close contact with agricultural production, many buildings have developed in rural areas that are useful for various functions, such as storage, production, and processing of agricultural products, thus creating the need for housing close to the workplace for the farmer and the farmer's family. With these aims, the agricultural territory has been populated, combining the primary production necessary for human nutrition with the control and the care of the agro-forestry territory.

The vernacular farm buildings can be defined as real sustainable buildings, thus they must be monitored and preserved. However, the process of abandoning the rural territory is leading to the abandonment of these farm buildings and, in some cases, to their complete demolition due to new building regulations. In the past, this process of wilderness and re-naturalization of the mountain territory was preferred both from an aesthetic and a planning point of view when compared to the concept of rural landscape [14]. Starting from the year 1990, the vision has changed due to the implementation of the European Landscape Convention (2000) and the EU Habitats Directive. In fact, there has been an increase in appreciation for traditional rural landscapes, rewilding them from both cultural and ecological points of view. Traditional rural landscapes have acquired ever greater value due to the demonstration of their uniqueness from cultural and historical points of view [15]. Their importance for the conservation of biodiversity has indeed become increasingly recognized due to several studies that have linked certain types of agricultural activities with the conservation of relevant animal and plant species. In particular, a strong connection between biodiversity and conservation/restoration of grassland is currently emerging $[16,17]$. This connection necessarily includes our rural heritage through conserving rural buildings. This is especially true for some Natura 2000 priority habitats, such as the semi-natural dry grasslands [18]. Moreover, if we also consider the increase in tourist flows in particularly rural areas [19], it is necessary to analyze the relationship between rural landscape and farm buildings, assessing the impacts they have had or could have within the ecological sustainability of landscape. In particular, the monitoring of the rural buildings and of the surrounding landscape, considering multidisciplinary and strong spatial components of the information, requires a suitable approach, which is now possible when based on new geographic technologies [20-22].

The present study is based on some key aspects for an integrated management of vernacular farm buildings in the context of the surrounding rural landscape. The first of these aspects-which may change in relation to territorial realities but that is common to many other territorial contexts-refers to the consistency of the geodatabases. Generally, the realization of heritage geodatabases through Geographic Information Systems (GIS) mapping is a common operation [23-26], but for rural heritage, often different types of data are used [27]. Indeed, georeferenced information is often incomplete or only partially usable; thus, in many cases, preliminary research, cataloguing, intersection of data, and verification are necessary. This analysis is mainly performed manually and is often very scattered in terms of resources and time [28]. 
Another important concept that needs to be considered in analyzing the relationships between rural buildings and the surrounding landscape is the survey parameters. In fact, a landscape can, in general, be analyzed from different points of view, thus a rural building can influence it both from an aesthetic point of view in a strict sense as well as from an ecological point of view [29]. Moreover, rural buildings themselves and their abandonment can be influenced by the characteristics proper of their landscape and territory as well as relevant urban planning policies [30-33]. The inputs and the outputs are multiple and often divergent, thus an integrated approach implemented through GIS may play a fundamental role. Therefore, it is necessary to put into practice important strategies to enhance and safeguard this important rural building heritage, starting from preliminary knowledge of the architectural characteristics of historic rural buildings and their relationship with the surrounding area. These possible intervention policies should appreciate the total impact of these buildings on the landscape using a holistic approach [34]. The studies of vernacular rural buildings, in most cases $[8,10,17]$, have made use of cadastral documentation, archival data, and surveys of the territory, thus the method presented in this work-the use of open data and a geospatial approach to identification [28] - differentiates them from the point of view of structural integrity and relates them to the surrounding rural landscape. This is certainly a new approach that can be useful for future developments of this theme, in particular for areas (such as the chosen study area) where there is a need to improve and expand knowledge about the built heritage and the rural landscape. Considering these assumptions, the objective of the present study is to propose a geospatial method for the evaluation of the relationships between farm buildings and rural landscape in order to provide public decision-makers with a useful tool for an integrated approach.

\section{Materials and Methods}

\subsection{Study Area}

The study area covers the entire territory of the Basilicata region (Southern Italy—see Figure 1), which is characterized by a traditional agricultural vocation and where the process of abandonment, rewilding, and fragmentation of rural areas is extremely topical $[35,36]$. Two main territorial compartments have been identified, corresponding with the administrative division of the two provinces: the province of Potenza, the regional capital, has mountainous and hilly terrain, including the Apennine Ridge and some of the most significant mountain ranges in southern Italy; the province of Matera is orographically constituted by the clay terraces of the Fossa Bradanica, which slope with hilly undulations towards the Apulian Region to the east and towards the coastal plain that hosts the mouths of the main Basilicata rivers to the south-east. This orographic conformation corresponding to completely different landscape characteristics has meant that, in the mountainous area, agricultural systems linked to small properties, to closed fields, and to a scattered and poor rural architecture have remained almost unchanged over time. The exception is the volcanic area of Mount Vulture, where the fertility of the soils and deforestation have allowed the establishment of important farms with the consequent creation of more complex rural types. The area belonging to the province of Matera, on the other hand, is both hilly and flat and has been subject to considerable effort to improve it, as the territory has played a leading role in the agricultural economy of the whole Basilicata region.

Over the last century, the agricultural landscape of Basilicata has undergone significant transformations. Although a "poor" rural economy has persisted, especially in the mountainous areas of the province of Potenza, considerable efforts have been made to improve economic and social conditions of the rural populations trying to support the agricultural sector. Rural typologies represent the most obvious indicators of the changes-not only economic, but also cultural一that have taken place in agricultural systems. This is particularly evident in the case of Basilicata, where large areas not "contaminated" by processes of agricultural mechanization still remain alongside regions involved in modernization. Moreover, there are vast areas where agricultural systems have evolved slowly, leaving visible traces of pre-existing settlements and production conditions. Another significant phenomenon 
is the abandonment of areas that, until a few decades ago, were used for grazing. Sheep farming, a family livelihood linked to the territory and residual in a few internal areas, has been replaced almost everywhere by stable farming. This has led, on the one hand, to the proliferation of building structures with morphological characteristics almost everywhere flattened by a typological homologation. On the other hand, the abandonment of pastures, which were long maintained through pastoral activity, has occurred with the consequent loss of such architectural heritage as sheepfolds and mountain shelters.

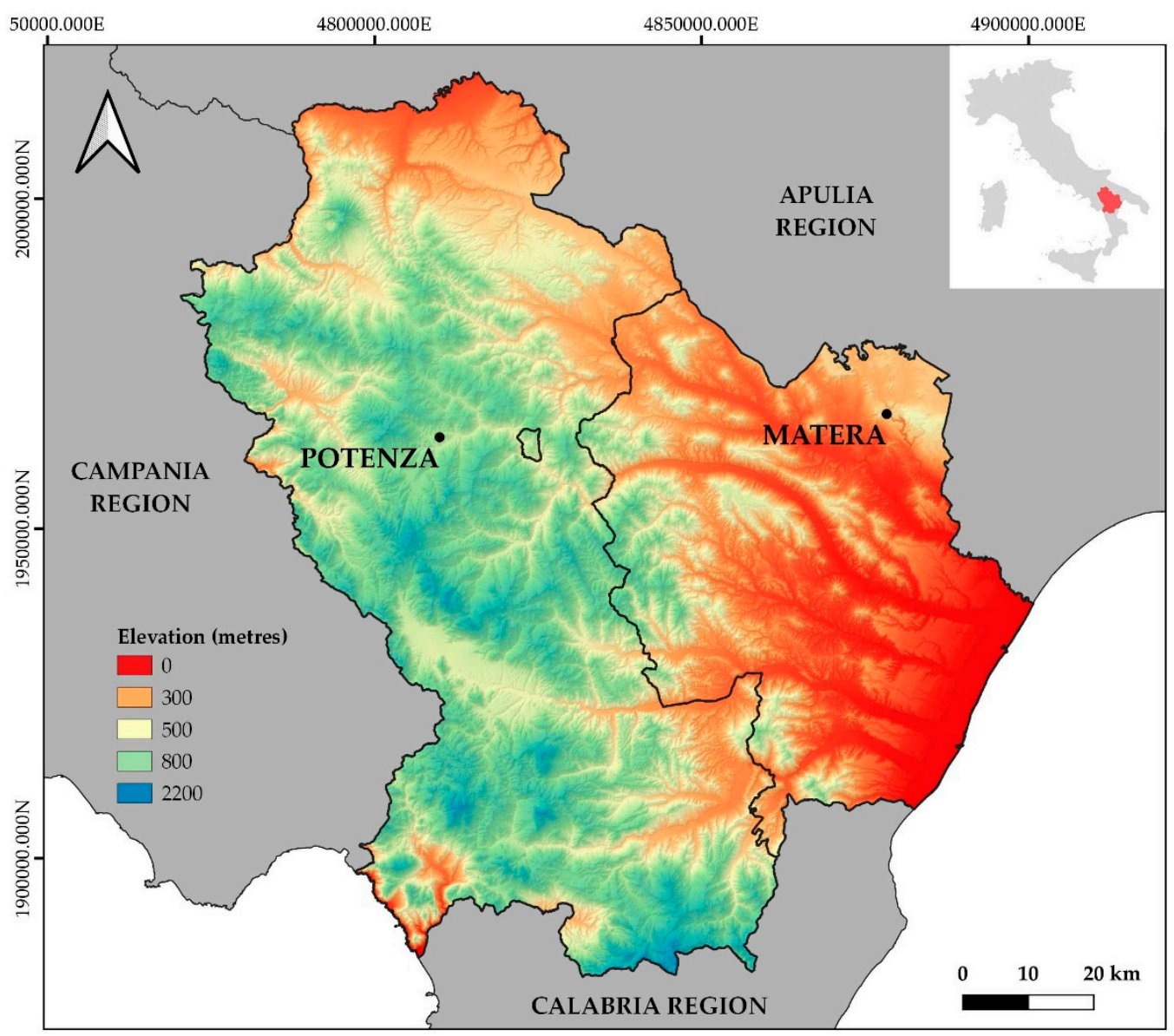

Figure 1. Location of study area with altimetric characterization, province division, and position of the two Province capitals. The grid is expressed in coordinate system ETRS89/LAEA Europe (EPSG:3035).

In an attempt to stimulate the tourism sector in the face of a widespread crisis in the agricultural sector, a proliferation of accommodation facilities located in buildings that were once rural or ex-novo built is currently occurring. The consequent introduction of new landscape elements has compatibility with the structural features of the landscape in ways that are complex and often questionable [37]. Typical elements are the masserie, the oldest evidence of the vernacular settlement scattered in Basilicata (the first traces of which date back to Greek colonization). Over time, the term has extended its meaning to cover all forms of rural settlement in the area, even if not managed by a farmer, and any independent rural farm connected to agriculture and livestock [38]. More than other buildings, the masserie determined and conditioned economic and social life of the region, until the mid-1900s representing the concretization of the history of the farmer who almost always lived under the control of the large landowners [39]. As reported by Franciosa [40], height variations play a fundamental role in the characterization of different architectural types. The buildings in mountainous areas and high hills are characterized by a simple shape, often on a single floor. On the other hand, in areas at lower altitudes or located near the coast, rural dwellings expand, and very often the buildings include settlers' residences and structures used for production or processing of agricultural products that are next to 
the main house of the farmer. In this case, we find forms that are more refined and rarer, offering more complex architectural solutions. Many of these rural buildings have assumed high cultural value due to their inclusion in Italy's cultural heritage list [41].

\subsection{Traditional Rural Buildings Geodatabase}

The census of rural buildings identified as masserie was the basic preliminary operation. It constituted the central geodatabase that will form the basis for implementing the system and the subsequent analysis. At present, there is no geo-referenced and official database of all the farms in Italy except for those with high architectural value and those protected through a specific cultural heritage code. The approaches are different and, in the past, mainly statistical/archival data have been used or direct surveys of the territory in some cases $[8,39,41]$. However, given the increase in complete and updated open source datasets [42,43], it was possible to carry out an effective census of all the rural buildings that were identified in the past with the toponym masseria (Figure 2). Crossing the national database of the Italian Geographical Military Institute (IGMI) toponyms [44] with the vectoral data created by the Basilicata Region in 2013 [45], it was possible to create a geodatabase consisting of all the buildings identified as masserie, further dividing them into abandoned and not abandoned using the information contained within the regional dataset. This distinction considers, among those abandoned, only farms that are definitively abandoned since they have been pulled down or ruined.
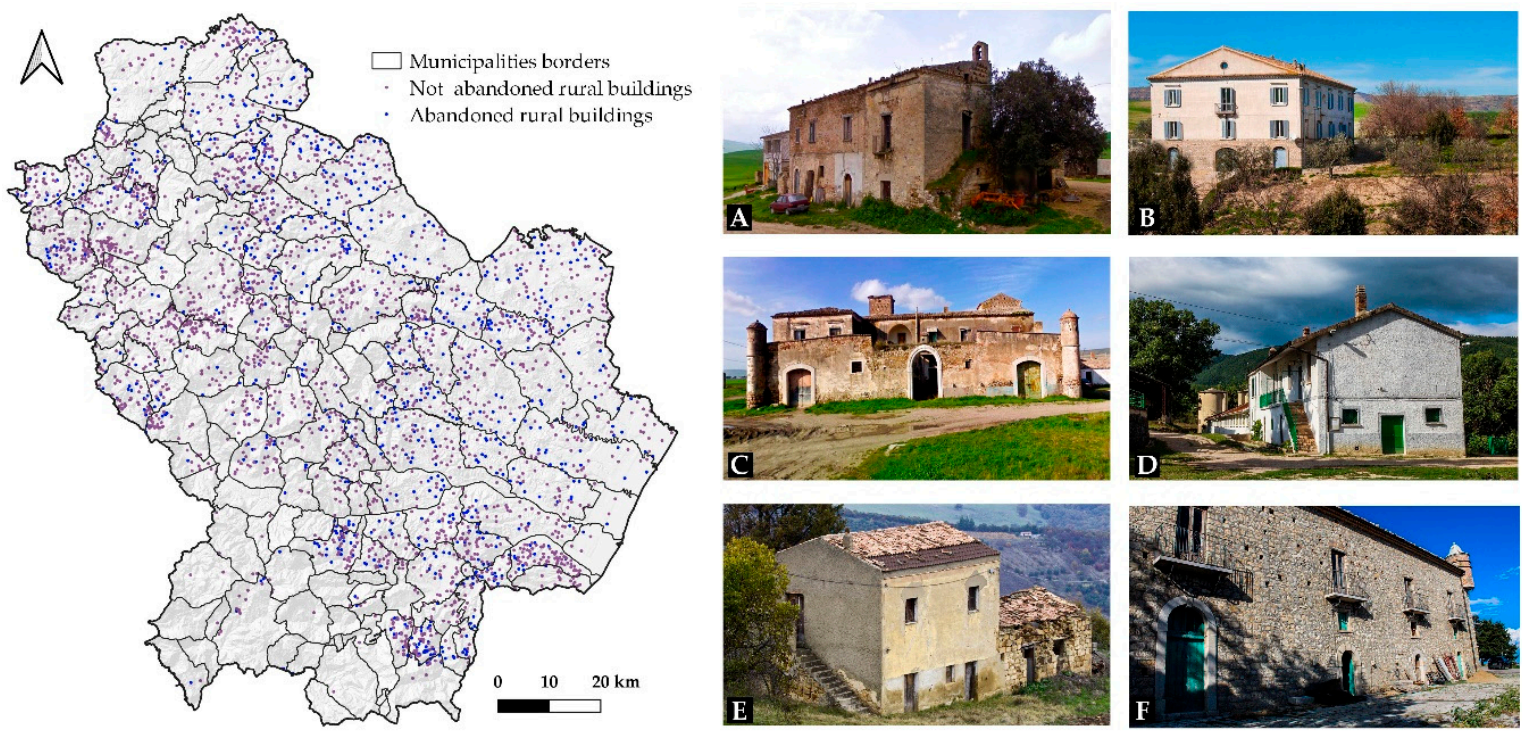

Figure 2. Map with distribution of abandoned and not-abandoned rural buildings in Basilicata Region. In the pictures, some of the rural buildings included in the database: abandoned (left) and not abandoned (right). (A) Masseria Di Pierro; (B) Masseria San Germano; (C) Masseria Parasacco; (D) Masseria Marsino Nicola; (E) Masseria Cillis; (F) Masseria San Zaccaria.

\subsection{Geospatial Analysis}

All operations of geospatial analysis were carried out with the open-source software QGIS 3.8 [46] while, for the statistical analysis, the R Project for Statistical Computing [47] was used.

\subsubsection{Rural Buildings: Distribution and Density}

The first geospatial analysis concerned the quantification and the distribution of traditional rural buildings located in the territory. This operation proved useful at the planning level to identify the compartments and the areas that need to be taken into account more in the local actions of management and restoration of the rural landscape. In addition to the classic building distribution at the level of municipality or other administrative limits, at the landscape level, it may be useful to use a 
concentration map to identify specific units of the landscape on which attention should be focused. Through the QGIS Heatmap plugin, it was possible to perform a kernel density estimation to create a density (so-called heatmap) raster of an input point vector layer. Therefore, the vector files of the points of interest were constituted by the centroids of the polygons that represented the abandoned and the not-abandoned rural buildings. The density was calculated considering the number of points in a given position, where a greater number of points generated greater values. Maps allow for easy identification of hotspots and grouping of rural buildings (Figure 3). By specifying the heatmap search radius, it was possible to map the density per $10 \mathrm{~km}^{2}$ of abandoned and not-abandoned rural buildings.

\subsubsection{Relationship with Farm Buildings Currently in Use for Agricultural Activities}

In order to assess the distribution of vernacular farm buildings over the regional territory as well as their relationship with the surrounding landscape, it was necessary to compare the connection that exists between the abandoned and the not-abandoned rural buildings with the other modern agricultural buildings currently in use. With this aim, we queried the regional geodatabase of buildings to extrapolate the position of buildings classified as "agricultural" and recently built. Through use of the plugin NNJoin [48], we were able to obtain a result layer as a vector file that contained all the attributes plus new information, including the distance between the joined nearest features. By setting the input layer as the one with abandoned and not-abandoned farms and the joined layer as one of the farm buildings currently in use for agricultural activities, it was possible to have a graduated map of each vernacular farm in relation to the orthogonal distance from the nearest agricultural building. In this way, we could characterize each farm in relation to this distance and hence identify the degree of isolation of individual buildings from the agricultural agglomerations currently active.

\subsubsection{Relationship with Road Network}

Similar to the previous operation, we carried out a spatial analysis of vernacular farm buildings and the road network. As far as the latter is concerned, a vector layer of the regional geodatabase was used. It included only the most important roads (motorways, main, secondary, and municipal roads), excluding minor roads such as paths, forest roads, and rural roads. This exclusion is because these types of roads, especially in some territorial contexts, are little exploited and managed as they are often privately owned and built to reach cultivated fields or land properties in general. Therefore, the main road network has a greater value in terms of usability and fruition. Using again the NNJoin plugin, it was possible to relate each rural building to the nearest road by associating the distance in meters. This operation allowed us to create a basic vector that can be used for static surveys and other, more complex spatial operations.

\subsubsection{Relationship with Topographical Parameters}

In order to understand the relationships between the abandoned and the not-abandoned vernacular farm buildings on the one hand and some important topographical variables that characterize the landscape on the other, a one-hectare-square buffer zone was created around each building. For each one of these square buffer zones, we calculated the average values of the following parameters:

- Altitude: height above sea level;

- Slope: based on first-order derivation estimation, it expresses the maximum gradient angle for each pixel in degrees.

In addition to these parameters, two more indices that are widely used for landform classification were also implemented [49,50]:

- Topographic Position Index (TPI): this index measures the topographic position of a central point as the difference between the elevation at this point and the average elevation within a certain established area. Negative TPI values represent the valleys and thus a lower position than the 
areas. Positive TPI values represent the ridges and therefore positions above the average refer to the surrounding environment. TPI values close to zero represent flat areas or areas with a constant slope (where the slope of the point is greater than zero). The topographic position is a phenomenon that depends on the scale [51].

- Terrain Ruggedness Index (TRI): to express the difference in elevation between adjacent cells of a digital elevation grid, the process automatically calculates the difference in elevation values between a cell in the central position and the eight cells that surround it. The higher the value is, the rougher the land is [52].

To calculate these indices, we used the Digital Elevation Model (DEM) of the Basilicata Region (cell size $5 \mathrm{~m}$ ) and calculated with the QGIS Raster Based Terrain Analysis Plugin. Subsequently, the statistics and the box-plot of altitude, slope, TPI, and TRI versus abandoned/not-abandoned rural buildings were elaborated to assess the separateness of buildings. This approach proved very useful for identifying whether abandonment could also be influenced by landscape landform and especially for identifying areas where rural buildings could be susceptible to abandonment.

\subsubsection{Visual Impact of Rural Buildings}

Viewshed analysis is a typical tool used to assess the visual impact of a rural building. Visibility strongly depends on the morphology of the terrain, but other parameters can influence the calculation of the viewpoint, such as the height of the observer as well as that of the observed object, vertical and horizontal viewing angles, the presence of different physical obstacles (e.g., vegetation, buildings, characteristics of the landform), the curvature of the Earth, and the weather conditions. The viewshed calculations involve the use of a Digital Surface Model (DSM) with a horizontal resolution of $5 \mathrm{~m}$, which includes vegetation, buildings, and other heights of vertical structures in order to partially mitigate the problem of alteration of visibility conditions from these elements $[53,54]$. To perform this calculation, we used the QGIS plug-in Viewshed Analysis [55]. It allows the facilitation of operations when it is necessary to set multiple different parameters and work with large amounts of data. The calculation allowed us to extrapolate the areas in which each rural building considered a valuable asset of the landscape - which improves cultural and aesthetic qualities—is visible within a pre-imposed radius of $1 \mathrm{~km}$. The result was an integer raster grid in which each cell stored the number of visible rural buildings. The sum of the areas with a radius of $1 \mathrm{~km}$ around each rural building provided the potential visible area. This potential visible area was compared with the real visible area, i.e., the area from which each rural building may be observed without being obscured by any obstacle, that came out from the raster grid. In this way, it was possible to identify the area in which each rural building had a greater visual impact in order to discriminate, at the level of large-scale planning, the areas that need more attention and monitor the aesthetic quality of the landscape [29].

\section{Results}

The creation of this geodatabase provided several kinds of information that can be employed as a source for an integrated spatial analysis of the rural landscape as well as a relevant planning and management tool for public decision-makers. In fact, due to the possibility of consulting and integrating different types of data, it was possible here to expand studies on the consistency of the rural heritage information that was gathered in the past, including rural buildings of considerable historical and architectural interest.

\subsection{Rural Buildings: Distribution and Density}

We identified a total of 3242 rural buildings associated with the toponym masseria. Among these, we classified just over $25 \%$ (n. 816) as ruined/abandoned. From the location of both types, it emerged that the farms are distributed throughout the region except for the south-west part. This needs further investigation to assess whether this lack is due to the actual inconsistency of rural buildings being 
defined as "farms" or another classification. From the clustering of the different typologies, it emerged that abandoned rural buildings, except for some areas, do not form important agglomerations; on the contrary, the not-abandoned rural buildings form large clusters in different areas of the region (Figure 3).
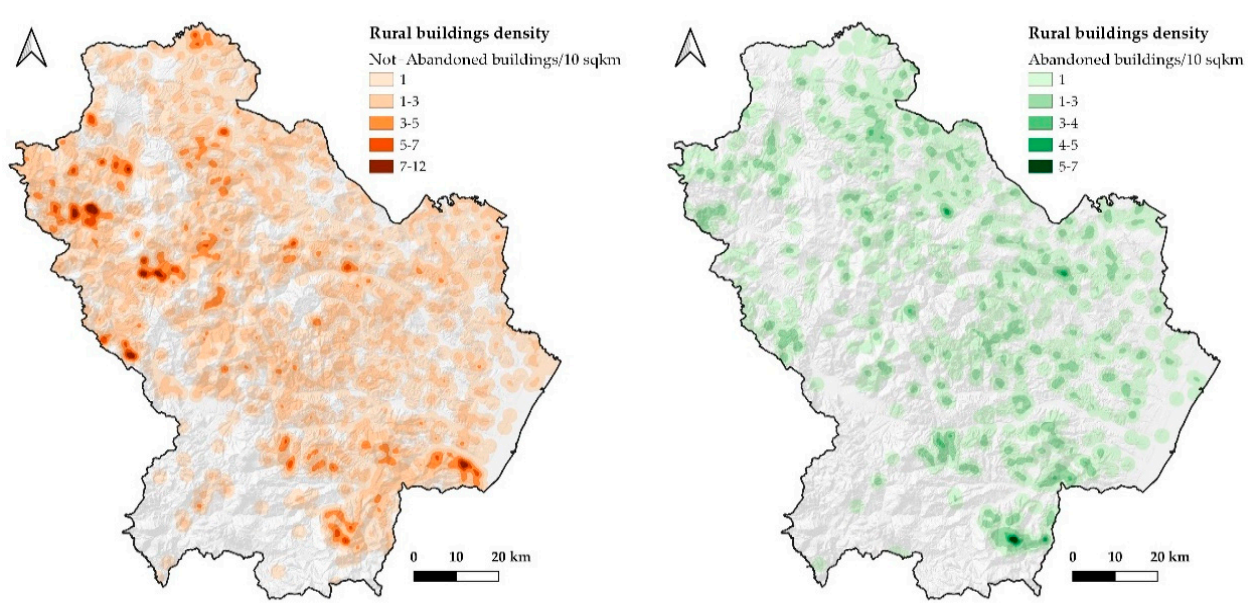

Figure 3. Map of rural buildings density calculated with Heatmap plugins expressed in number per 10 sq. km. Abandoned (left) and not-abandoned (right).

\subsection{Relationship with Farm Buildings Currently in Use for Agricultural Activities}

Concerning the analysis of the relationship between vernacular rural buildings-abandoned and not abandoned-with the linear distance with respect to new farm buildings currently in use for agricultural activities (Table 1), it can be seen that abandoned rural buildings are, on average, $532.76 \mathrm{~m}$ away from new rural buildings (Figure 4), more than twice as much as not-abandoned buildings $(256.95 \mathrm{~m})$. This shows a certain tendency for vernacular farm buildings to be far from the most important agricultural centers. There is a certain variability in the distribution of data in the different distance classes (Figure 5) compared to the not-abandoned ones, which are instead almost totally distributed in the first distance class. The distance from the new rural centers for agricultural activities is certainly an important parameter to be considered. This method allowed us to quantify it and to include it in spatial operations in a fairly effective and accurate way for the evaluation of the potential impacts of traditional buildings on the landscape.
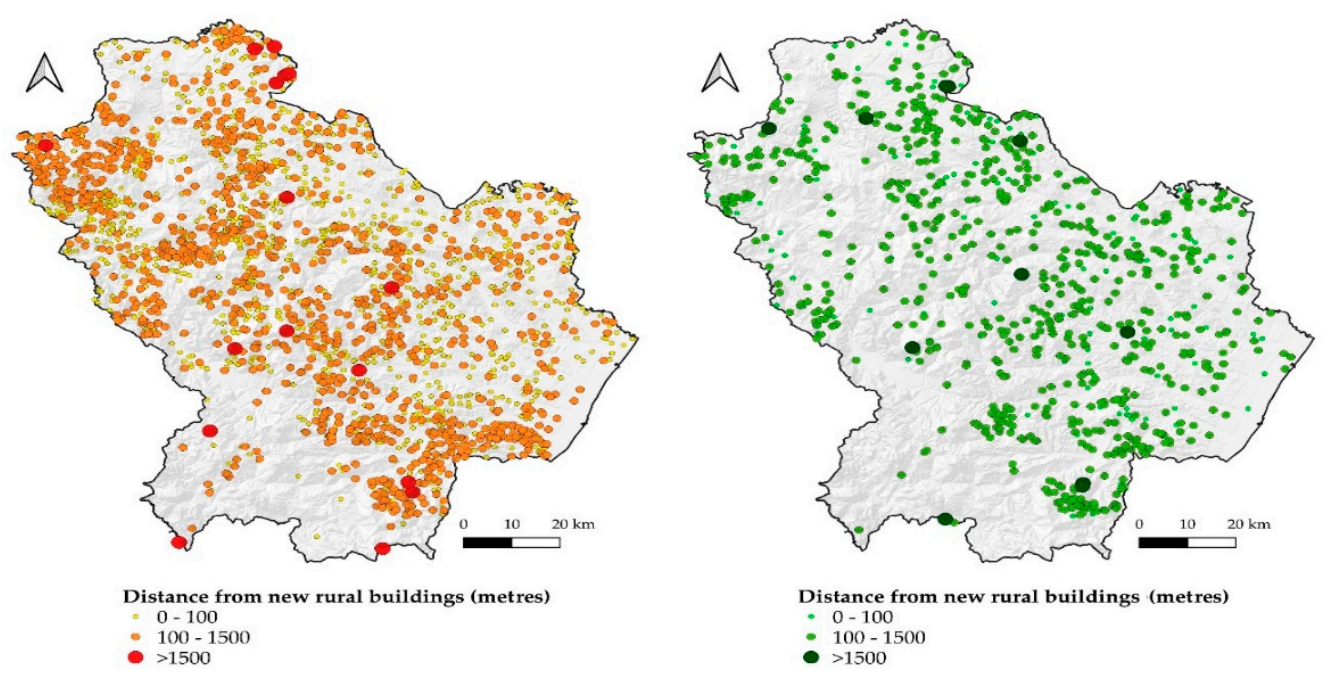

Figure 4. Map of the distance of the abandoned (left) and the not-abandoned (right) vernacular rural building from the new farm buildings currently in use for agricultural activities. 
Table 1. Average, minimum, maximum, and standard deviation of the distance (expressed in meters) of each typology of vernacular rural buildings from new farm buildings currently in use for agricultural activities.

\begin{tabular}{lcccc}
\hline Rural Buildings & Mean & Min & Max & Std. Deviation \\
\hline Abandoned & 532.76 & 19.15 & 2355.63 & 382.48 \\
Not Abandoned & 256.95 & 16.25 & 4210.21 & 355.76 \\
\hline
\end{tabular}
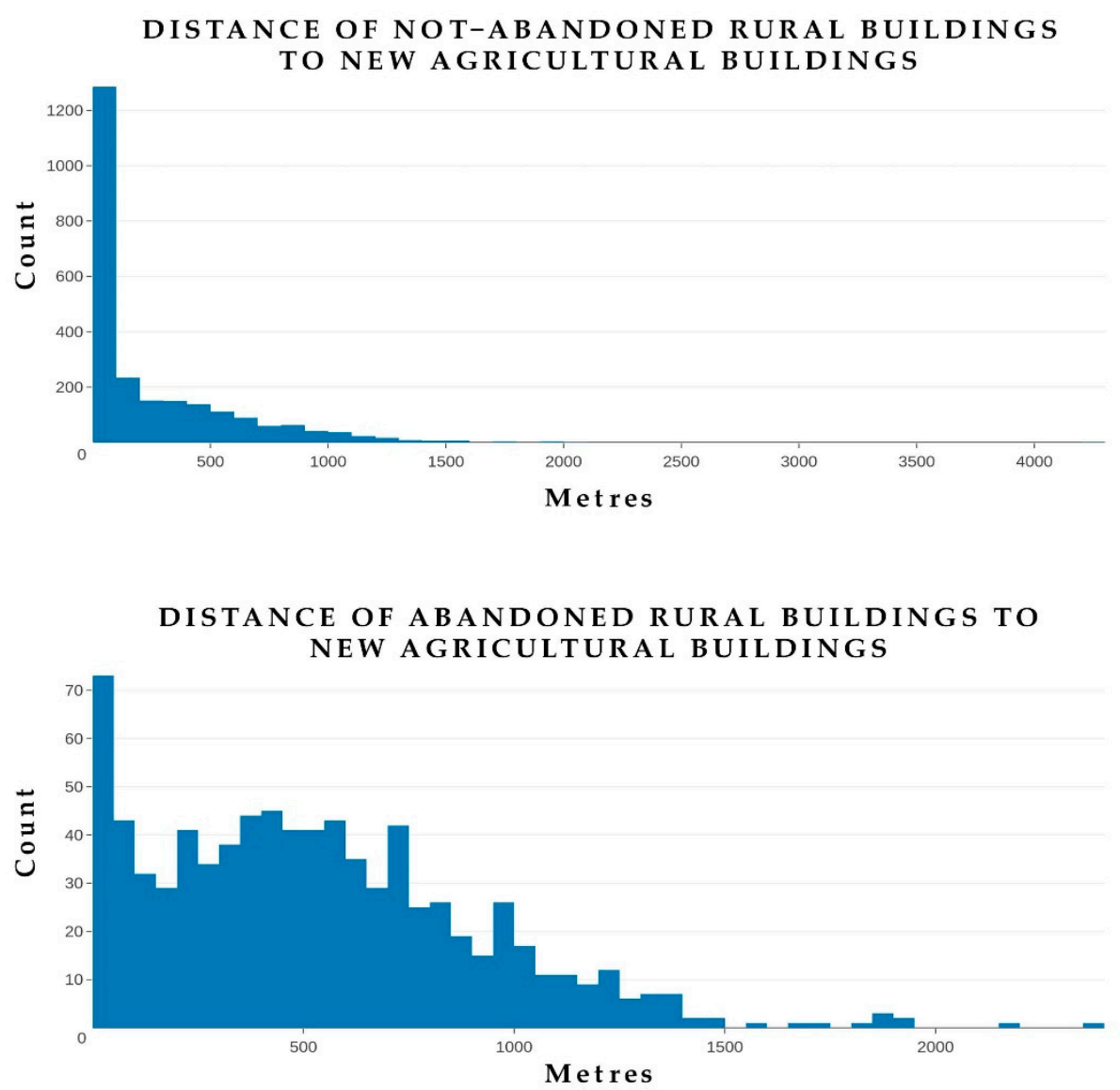

Figure 5. Distribution of not-abandoned vernacular rural buildings (above) and abandoned vernacular rural buildings (below) with respect to the distance from new farm buildings currently in use for agricultural activities.

\subsection{Relationship with Road Network}

The analysis carried out for the distance to the main road network showed that the more isolated the farms were, i.e., more distant from the main roads, the more their abandonment relentlessly continued (Table 2). The average distance from the main road network is $46.68 \mathrm{~m}$ for not-abandoned buildings with almost all of the farms being distributed within $100 \mathrm{~m}$ (Figure 6). Also, many of the abandoned farms fall within the first class (Figure 7), but they are more distributed in the other classes with a much higher (about $135 \mathrm{~m}$ ) average value. 
Table 2. Average, minimum, maximum, and standard deviation of the distance in meters of the two typologies of vernacular farm buildings from the main road network.

\begin{tabular}{lcccc}
\hline Rural Buildings & Mean & Min & Max & Std. Deviation \\
\hline Abandoned & 135.01 & 4.54 & 918.01 & 158.23 \\
Not Abandoned & 48.68 & 2.92 & 1152.65 & 79.97 \\
\hline
\end{tabular}
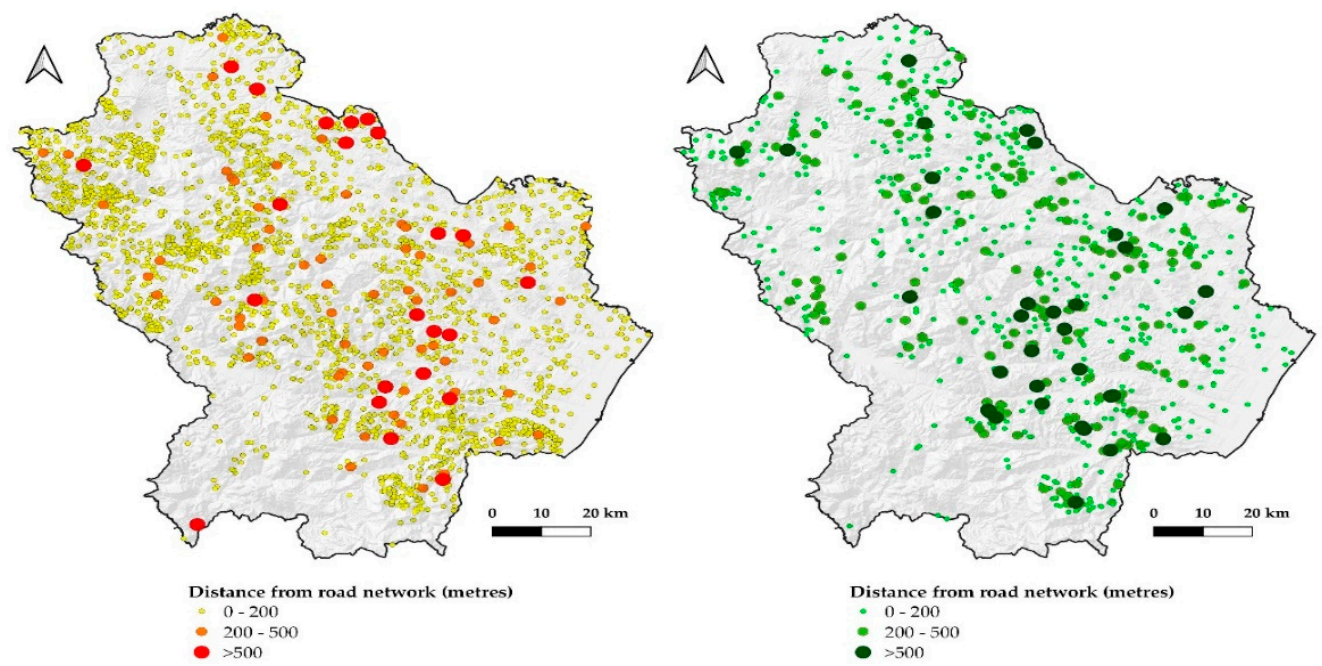

Figure 6. Map of the distance of the abandoned (left) and not-abandoned (right) vernacular rural buildings from the main road network.
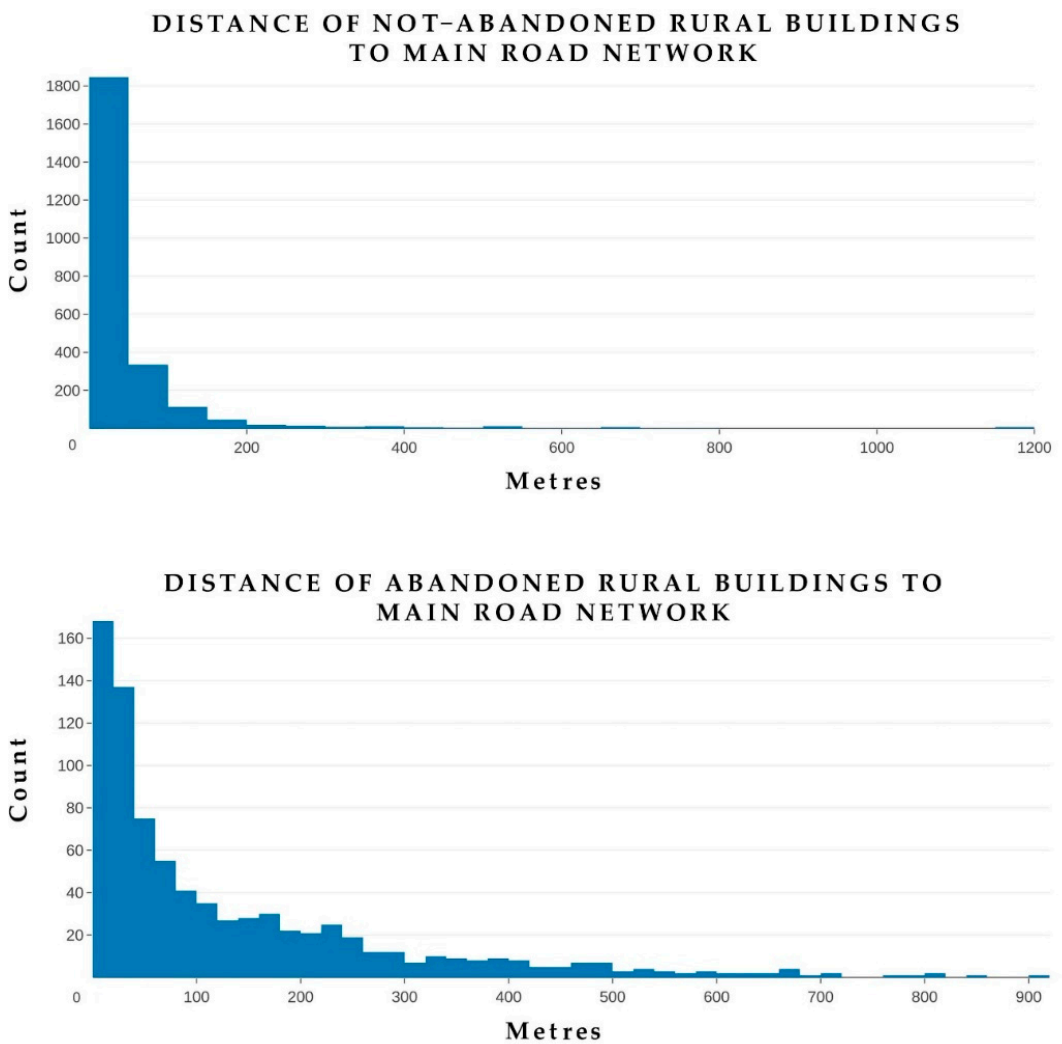

Figure 7. Distribution of not-abandoned vernacular rural buildings (above) and abandoned vernacular rural buildings (below) with respect to the distance from the main road network. 


\subsection{Relationship with Topographical Parameters}

As far as the relationship between topographical parameters and rural buildings is concerned, what emerged in general is that there is no parameter showing a clear influence on the abandonment of rural buildings (Figure 8). Analyzing their average values in detail (Table 3), we note that, in general, the rural buildings (abandoned and not) are located in areas of the region with an average altitude $500 \mathrm{~m}$ above sea level in mid-slope areas (with slope value around $10-11^{\circ}$ and TPI with positive values tending toward hilltops). From the differentiated analysis, it emerged that the abandonment is more distributed along all the values for the four topographical parameters when compared to the values of the not-abandoned farms (Figure 9).
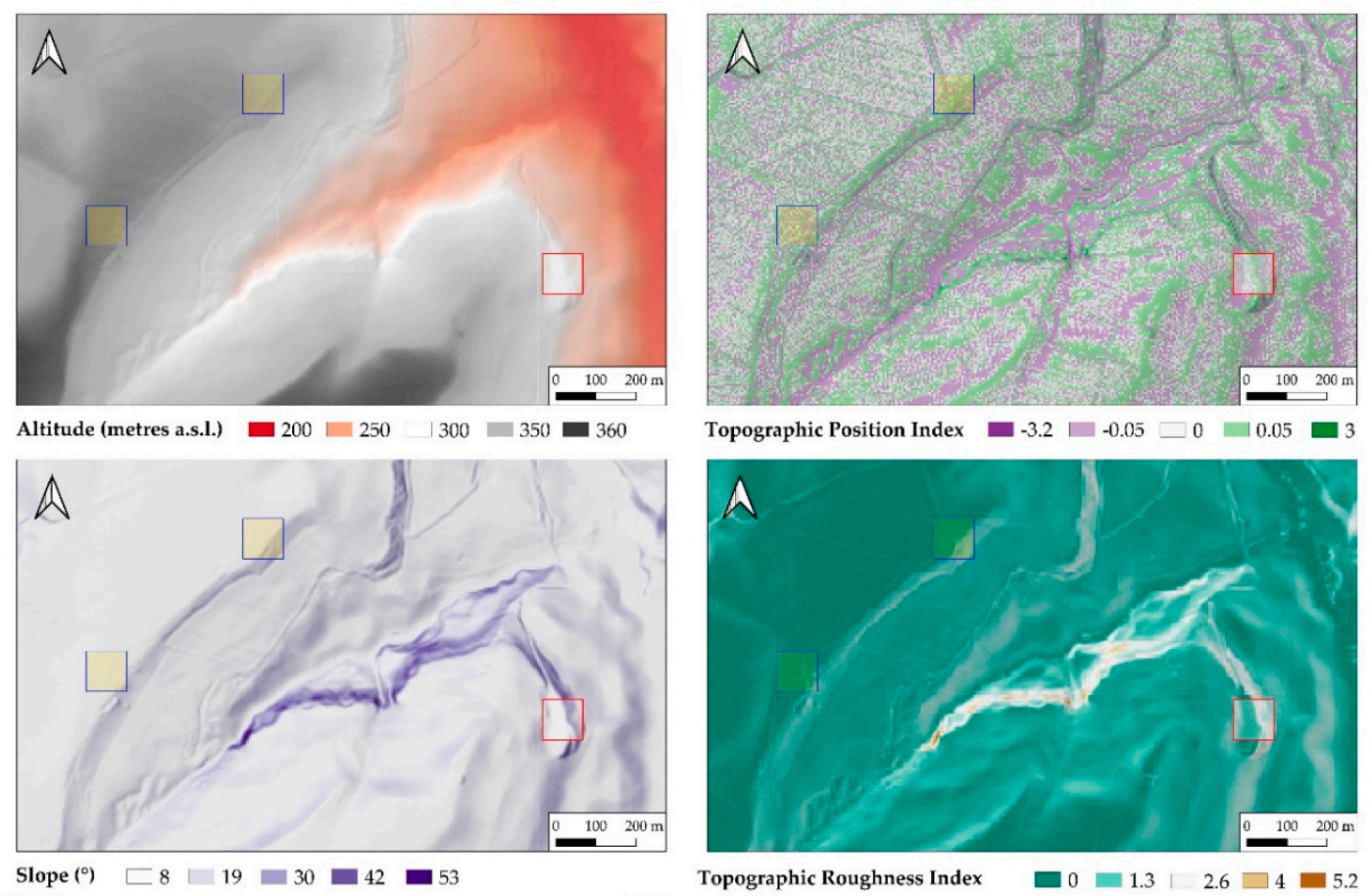

Buffer not-abandoned "Masserie"

Buffer abandoned "Masserie"

Figure 8. Extract of a part of the study area representing the four different topographical parameters. As an example, the square buffers of some types of farms in the area are also reported.

Table 3. Average and standard deviation of the four topographical parameters [altitude, slope, Topographic Position Index (TPI), Terrain Ruggedness Index (TRI)] considered for analyzing abandoned and not-abandoned rural buildings.

\begin{tabular}{lcccc}
\hline & Altitude (m) & Slope $\mathbf{(}^{\circ}$ & TPI & TRI \\
\hline Abandoned & $506.27 \pm 276.15$ & $11.67 \pm 5.87$ & $0.022 \pm 0.029$ & $0.845 \pm 0.436$ \\
Not Abandoned & $551.33 \pm 277.89$ & $10.24 \pm 5.12$ & $0.019 \pm 0.028$ & $0.744 \pm 0.377$ \\
\hline
\end{tabular}


NOT - ABANDONED
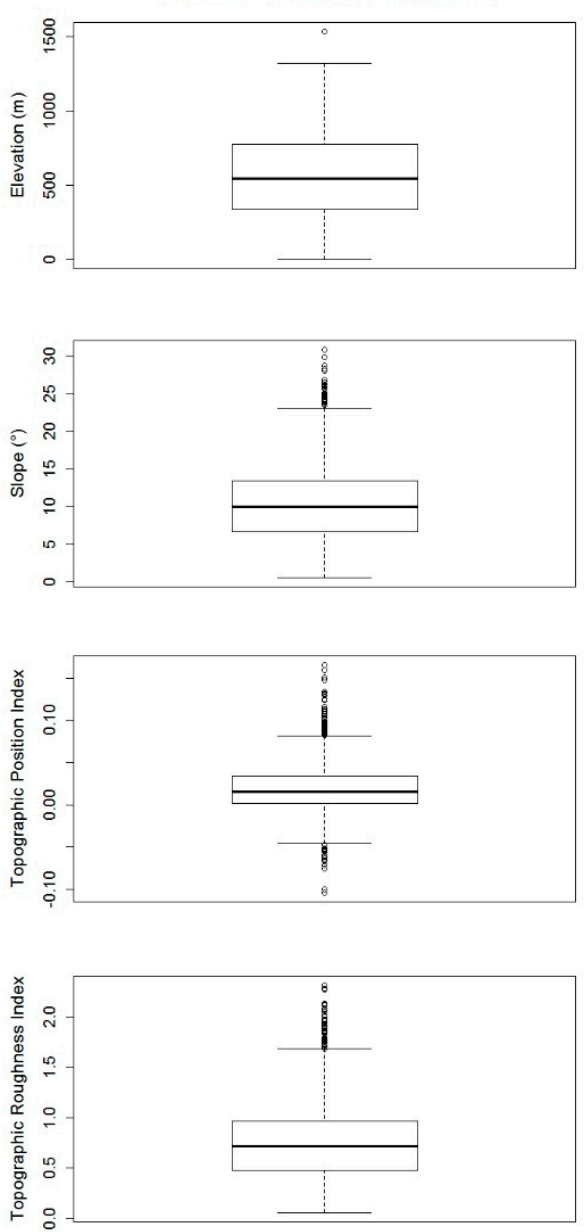

ABANDONED
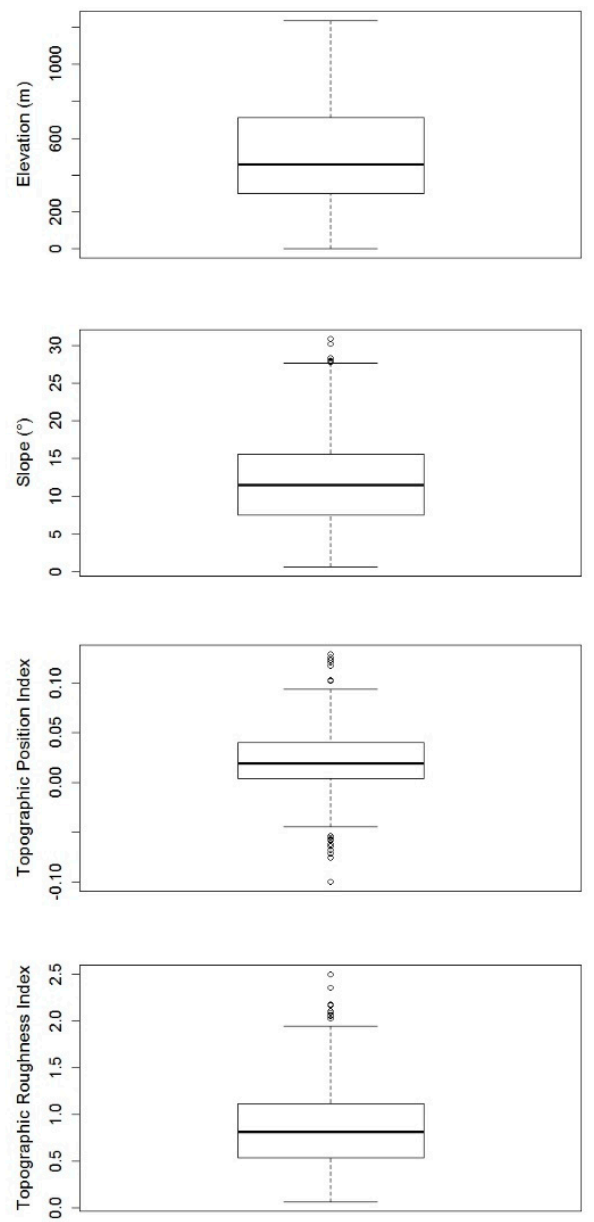

Figure 9. Box plots of the relationships between topographical parameters (altitude, slope, TPI, and TRI) for abandoned and not-abandoned vernacular rural buildings. Circles indicate outliers; horizontal lines inside the box indicate the median value of each parameter. The bottom of the box is at the first quartile ( $25 \%$ of distribution), and the top is at the third quartile ( $75 \%$ of distribution) value, while whiskers indicate variability outside the upper and the lower quartiles.

\subsection{Visual Impact of Rural Buildings}

The analysis of the inter-visibility between landscape and rural buildings enabled us to estimate, on the basis of the parameters set in the plugin, the total surface area of the potentially visible area with $1 \mathrm{~km}$ radius, which is visible from the rural buildings. This total potential visible area is equal to 256,224 ha for abandoned rural buildings and 761,764 ha for not-abandoned rural buildings. The total real visible areas, which were obtained after excluding the area inside the $1 \mathrm{~km}$ radius from which each rural building may not be observed (since they are hidden by some obstacles), were respectively $20.1 \%$ and $26.9 \%$ of the whole potential visible area (Table 4 ). Therefore, generally, we can conclude that the rural buildings considered have a relatively limited visible impact area. Moreover, the visible area for both types of buildings (abandoned and not abandoned) and the greatest visual impact is limited to some individual buildings (Figure 10). In Table 4, it is possible to notice that just over $85 \%$ and almost $93 \%$ of the visible area include only one building. It should also be noted that, with regard to the abundant buildings that have a greater interest in the impact they can have on the landscape, the visible area is almost exclusively linked to isolated farms (almost 100\% if we also consider class 2). For buildings that are not abandoned, the situation is similar, but there are also values for the upper classes. Highlighting these areas through this methodology may reveal an important issue for 
planning purposes because, in order to have an impact on the surrounding landscape, these are the areas that are most visible. Therefore, they need more accurate monitoring in order to avoid radical transformations of their rural landscape identity.

Table 4. Surface in hectares and percentage of number of visible buildings (abandoned and not).

\begin{tabular}{ccccc}
\hline & \multicolumn{2}{c}{ Not Abandoned } & \multicolumn{2}{c}{ Abandoned } \\
\hline No. of Visible Buildings & ha & \% & ha & \% \\
\hline 1 & $174,669.12$ & 85.187 & $47,811.12$ & 92.705 \\
2 & $24,256.21$ & 11.830 & 3390.22 & 6.574 \\
3 & 4619.56 & 2.253 & 298.76 & 0.579 \\
4 & 1176.97 & 0.574 & 59.97 & 0.116 \\
5 & 271.12 & 0.132 & 13.07 & 0.025 \\
6 & 48.96 & 0.024 & 0.03 & 0.001 \\
7 & 4.81 & 0.002 & & \\
8 & 1.98 & 0.001 & & 100 \\
9 & 0.03 & 0.001 & & $20.1 \%$ \\
Visible Area & & & & \\
Total Real & $205,041.93$ & 100 & $51,573.17$ & $256,224.00$ \\
\hline
\end{tabular}

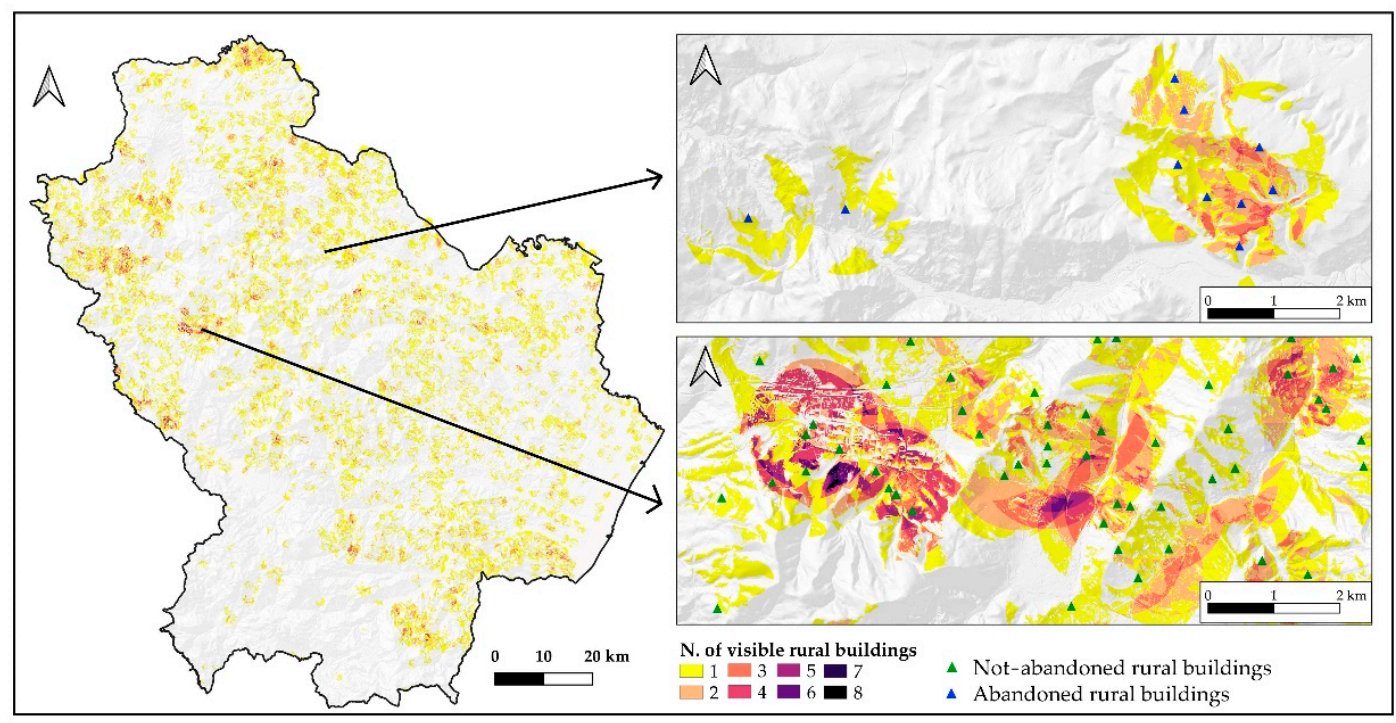

Figure 10. Result of the cumulative viewshed analysis for the whole study area. On the right are details of two parts of the study area in which the result is expressed as the number of visible abandoned and not-abandoned vernacular rural buildings.

\section{Discussion}

The continuous increase in both descriptive and geographical open data at all levels leads to increasingly easier retrieval of useful information for issues related to sustainable management territory and landscape. In parallel with this considerable increase in data, there has been a continuous improvement in software and geographical information techniques. These tools allow, in addition to better verification of the accuracy of the data, a diversification of analysis and possible studies. Regarding the elaboration of the geodatabase with different typologies of rural buildings, much depends on the data available from the relevant local authorities. For regions of Southern Italy, the combined approach between regional vector cartography and the toponyms database provided by the Italian Geographic Military Institute can be the first accurate investigation, as demonstrated in other studies [23]. In addition, this approach can be useful in identifying other types of traditional rural structures of considerable interest. Obviously, for a complete realization of a geodatabase 
that is useful for management, recovery, and enhancement of these rural buildings, it is necessary to make a detailed survey of each one of them that reports the name masseria. The differentiation between abandoned and not-abandoned buildings also depends on the consistency of the database. Alternatively, manual approaches can be used to identify them [17]. The potential of semi-automatic procedures for classifying very high-resolution images or orthophotos to assess the consistency of individual buildings [56] should be investigated as well.

Finally, the creation of concentration maps proved a valid tool for identifying areas of investigation released from the physical location of the building. The abandonment of old rural buildings and their farmlands in general, in addition to causing the loss of an irreversible cultural and ethno-anthropological heritage, is the phenomenon that has the greatest impact on landscape sustainability. This issue requires predictive methods that are able to take into account some new techniques such as machine learning [57]. Indeed, the main aim of this work is to provide a reliable method to better evaluate the implementation of suitable management practices that aim to examine the integrity, the resilience, and the sustainability of some typical historical rural landscapes. The density of abandoned farms is especially important because it allows us to identify areas where the phenomenon is more concentrated and then go into more detail to understand relevant drivers and causes.

With regard to evaluating the spatial relationships between the two categories of rural buildings (i.e., abandoned and not-abandoned) and some aspects of the landscape, the method proposed here takes into account some aspects that have an influence on abandonment [58]. At the same time, it also gives information about how the different types of buildings have impacted in the past as well as how they could do so in the future so as to identify the areas that may be most susceptible to abandonment and to reduce the possible impacts $[59,60]$ with a view to a more sustainable management of the landscape.

The distance from roads is one of the factors that has most determined the phenomenon of abandonment. Considering the importance of this variable, it is necessary to go into even more detail about this parameter by more thoroughly differentiating the different types of roads. At the level of landscape planning, rural buildings not yet abandoned that are close, for example, to areas of high natural value [29] and that are furthest from the main roads are those which more attention must be given due to the ecological impact that could lead to their abandonment. What mainly arises from the analysis of the relationships between rural buildings and topographical variables is that they have an importance in the dynamics of abandonment and transformation of the rural landscape [61]. In this case study, however, it did not clearly emerge.

Finally, the analysis of the inter-visibility between landscape and farms has proven very useful for evaluating, in spatial terms, the area of visual influence that each type has. This method can be very useful in terms of landscape planning for identifying the areas of visual influence of each farm and for monitoring and possibly directing the actions of conservation and/or restoration of activities related to rural buildings. For example, the areas with the highest visibility and linked to a greater number of abandoned rural buildings are certainly the areas that need more attention from the point of view of sustainable landscape planning. This is in order to prevent this abandonment from leading to radical transformations from the point of view of land use and cover and therefore to a loss of the identity typical of that specific rural landscape. Moreover, starting from this first type of analysis, it would be possible to address the actions of tourism enhancement due to the integration within this geospatial analysis of the network of scenic roads by assessing the quality of the landscape as well [62].

With this method, it was possible to identify some parameters that, for the study area, have most influenced abandonment $[63,64]$. In order to consider the visual aspect of the area around each farm, the proposed technique provided a fundamental overview to identify, for example, the most visible rural buildings from a stretch of scenic road, which would need more attention in case of abandonment or change of land use. This integrated method proposed here can also be modified and calibrated in relation to the setting of a Visual Impact Assessment [65]. Since it takes into account some parameters, it would prove a useful tool for planners to assess the relationship between landscape and rural 
buildings. In addition, the parameters can be expanded to take into account geological, socio-economic, and cultural variables, hence contributing to a necessary holistic approach [66]. In conclusion, this integrated method could be very important to realizing basic datasets that could be useful for evaluating whether buildings can have a positive or a negative influence on landscape ecology [16] by introducing the relationships with the cultivated fields annexed to each single building as well. Moreover, it can be useful in improving knowledge about the field of research of landscape sustainability [67], as it is a spatial method based on a temporal and a multi-scale approach that combines different aspects that could be useful for the control of different ecosystem services and strictly perceptive features.

\section{Conclusions}

The rural building plays a crucial role not only in sustainable and resilient growth of agriculture but also in the sustainability of typical rural landscapes, ecosystem service providers, and socio-cultural activities. For evaluating the implementation of suitable management practices that aim to preserve their rurality, GIS geospatial analysis can be used, taking into account different disciplines and time scales. In this study, a method to verify some results for the study area in which there are typical rural landscapes of the Mediterranean area was implemented. Indeed, the present paper confirmed the main results emerging from recent studies in the scientific literature, i.e., that many farm buildings develop a fundamental—if not essential—effect for the preservation, the monitoring, the management, and the general sustainability of the rural landscape. In particular, rural landscape sustainability can be achieved through a more rational consumption of resources, the fight against environmental degradation, and the maintenance of stable ecosystem balances, all actions that can be carried out through the return to traditional agriculture. This transition necessarily passes through the recovery and the enhancement of vernacular farm buildings, which possess important ecological, socio-economic, and cultural values. In this way, it is also possible to preserve the rural building heritage as architectural and cultural evidence of a certain way of living in synergy with the surrounding landscape heritage. Geographic technologies have proven to be a powerful tool for implementing new ways to enhance and conserve the agricultural built heritage in synergetic action with the surrounding rural landscape. The relevant cataloguing of historical rural buildings with geo-referenced information and the subsequent use of them as a basis for more complex spatial analysis allow the assessment of the role and the impact of these buildings within the surrounding context with a view to more sustainable land management. This approach would be a suitable tool for future possible application in rural landscape analysis, planning, and management.

Author Contributions: The design and conduct of this research is equally shared between the authors. The three authors collaborated to produce this paper. G.C. and D.S. proposed and developed the research design, methodology, manuscript writing, and data analysis, P.P. supervised the work, provided additional comments on the results and interpretation, reviewed and approved the final version. All authors have read and agreed to the published version of the manuscript.

Funding: No founding for this research activities.

Conflicts of Interest: The authors declare no conflict of interest.

\section{References}

1. MacDonald, D.; Crabtree, J.; Wiesinger, G.; Dax, T.; Stamou, N.; Fleury, P.; Gutierrez, L.J; Gibon, A. Agricultural abandonment in mountain areas of Europe: Environmental consequences and policy response. J. Environ. Manag. 2000, 59, 47-69. [CrossRef]

2. Agnoletti, M. The Italian Historical Rural Landscape: Cultural Values for the Environment and Rural Development; Agnoletti, M., Ed.; Springer: Dordrecht, The Netherlands, 2012.

3. Van der Zanden, E.H.; Verburg, P.H.; Schulp, C.J.E.; Verkerk, P.J. Trade-offs of European agricultural abandonment. Land Use Policy 2017, 62, 290-301. [CrossRef] 
4. Perpiña Castillo, C.; Kavalov, B.; Diogo, V.; Jacobs-Crisioni, C.; Batista e Silva, F.; Lavalle, C. Territorial Facts and Trends in the EU Rural Areas within 2015-2030. Available online: https:/www.researchgate.net/ publication/333508542_Territorial_Facts_and_Trends_in_the_EU_Rural_Areas_within_2015-2030 (accessed on 27 August 2019).

5. Stoate, C.; Báldi, A.; Beja, P.; Boatman, N.D.; Herzon, I.; van Doorn, A.; de Snoo, G.R.; Rakosy, L.; Ramwell, C. Ecological impacts of early 21st century agricultural change in Europe-A review. J. Environ. Manag. 2009, 91, 22-46. [CrossRef] [PubMed]

6. Navarro, L.M.; Pereira, H.M. Rewilding abandoned landscapes in Europe. Ecosystems 2012, 15, 900. [CrossRef]

7. Fuentes, J.M. Methodological bases for documenting and reusing vernacular farm architecture. J. Cult. Herit. 2010, 11, 119-129. [CrossRef]

8. Picuno, P. Use of traditional material in farm buildings for a sustainable rural environment. Int. J. Sustain. Built Environ. 2016, 5, 451-460. [CrossRef]

9. Fuentes, J.M.; Gallego, E.; García, A.I.; Ayuga, F. New uses for old traditional farm buildings: The case of the underground wine cellars in Spain. Land Use Policy 2010, 27, 738-748. [CrossRef]

10. Picuno, C.A.; Laković, I.; Roubis, D.; Picuno, P.; Capetanović, A. Analysis of the characteristics of traditional rural constructions for animal corral in the Adriatic-Ionian area. Sustainability 2017, 9, 1441. [CrossRef]

11. Hernández, J.; García, L.; Ayuga, F. Integration methodologies for visual impact assessment of rural buildings by geographic information systems. Biosyst. Eng. 2004, 88, 255-263. [CrossRef]

12. Cañas, I.; Ayuga, E.; Ayuga, F.A. Contribution to the assessment of scenic quality of landscapes based on preferences expressed by the public. Land Use Policy 2009, 26, 1173-1181. [CrossRef]

13. Jeong, J.S.; García-Moruno, L.; Hernández-Blanco, J. Integrating buildings into a rural landscape using a multi-criteria spatial decision analysis in GIS-enabled web environment. Biosyst. Eng. 2012, 112, 82-92. [CrossRef]

14. Agnoletti, M. Rural landscape, nature conservation and culture: Some notes on research trends and management approaches from a (southern) European perspective. Landsc. Urban Plan 2014, 126, 6673. [CrossRef]

15. ICOMOS. ICOMOS-IFLA Principles concerning rural landscapes as heritage. In Proceedings of the 19th ICOMOS General Assembly and Scientific Symposium, New Delhi, India, 11-15 December 2017; ICOMOS: Paris, France.

16. McKenzie, P.; Cooper, A.; McCann, T.; Rogers, D. The ecological impact of rural building on habitats in an agricultural landscape. Landsc. Urban Plan 2011, 101, 262-268. [CrossRef]

17. Haller, A.; Bender, O. Among rewilding mountains: Grassland conservation and abandoned settlements in the Northern Apennines. Landsc. Res. 2018, 43, 1068-1084. [CrossRef]

18. Calaciura, B.; Spinelli, O. Management of Natura 2000 Habitats: 6210 Semi-natural Dry Grasslands and Scrubland Facies on Calcareous Substrates (Festuco-Brometalia) (*Important Orchid Sites); European Commission: Brussels, Belgium, 2008.

19. Ana, M. Tourism industry in the new Europe: Trends, policies and challenges. In Proceedings of the International Conference on Business Excellence, Bucharest, Romania, 30-31 March 2017; Volume 11, pp. 493-503. Available online: https://content.sciendo.com/configurable/contentpage/ journals $\$ 002$ fpicbe $\$ 002 \mathrm{f} 11 \$ 002 \mathrm{f} 1 \$ 002$ farticle-p493.xml (accessed on 27 August 2019).

20. Cano, M.; Garzón, E.; Sánchez-Soto, P.J. Preservation and conservation of rural buildings as a subject cultural tourism: A review concerning the application of new technologies and methodologies. J. Tour. Hosp. 2013, 2, 115.

21. Jeong, J.S.; Garcia-Moruno, L. The study of building integration into the surrounding rural landscape: Focus on implementation of a web-based MC-SDSS validation by two-way participation. Land Use Policy 2016, 57, 719-729. [CrossRef]

22. Palmisano, G.O.; Loisi, R.V.; Rocchi, G.R.; Boggia, L.; Roma, A.R.; Dal Sasso, P. Using analytic network process and dominance-based rough set approach for sustainable requalification of traditional farm buildings in Southern Italy. Land Use Policy 2016, 59, 95-110. [CrossRef]

23. Martinez-Graña, A.M.; Goy, Y.; Goy, J.L.; Zazo Cardeña, C. Natural heritage mapping of the las batuecas-sierra de francia and quilamas nature parks (SW Salamanca, Spain). J. Maps 2011, 7, 600-613. [CrossRef]

24. Biscione, M.; Danese, M.; Masini, N. A framework for cultural heritage management and research: The Cancellara case study. J. Maps 2018, 14, 576-582. [CrossRef] 
25. Blanco, A.; de Bustamante, I.; Pascual-Aguilar, J.A. Using old cartography for the inventory of a forgotten heritage: The hydraulic heritage of the community of Madrid. Sci. Total Environ. 2019, 665, 314-328. [CrossRef]

26. Inventario Nazionale dei Geositi. Available online: http://sgi.isprambiente.it/GeositiWeb/default.aspx? ReturnUrl=\%2fgeositiweb\%2f (accessed on 27 August 2019).

27. Ruggiero, G.; Parlavecchia, M.; Dal Sasso, P. Typological characterisation and territorial distribution of traditional rural buildings in the Apulian territory (Italy). J. Cult. Herit. 2019, 39, 278-287. [CrossRef]

28. Parlavecchia, M.; Pascuzzi, S.; Anifantis, A.S.; Santoro, F.; Ruggiero, G. Use of GIS to evaluate minor rural buildings distribution compared to the communication routes in a part of the Apulian territory (Southern Italy). Sustainability 2019, 11, 4700. [CrossRef]

29. Statuto, D.; Cillis, G.; Picuno, P. GIS-based analysis of temporal evolution of rural landscape: A case study in Southern Italy. Nat. Resour. Res. 2019, 28, 1-15. [CrossRef]

30. Cillis, G.; Statuto, D.; Picuno, P. Valorisation of historical farm buildings for protecting the rural landscape. In Proceedings of the 47th Symposium on: Actual Tasks on Agricultural Engineering-ATAE 2109, Opatija, Croatia, 5-7 March 2019.

31. Shi, T.; Li, X.; Xin, L.; Xu, X. Analysis of farmland abandonment at parcel level: A case study in the mountainous area of China. Sustainability 2016, 8, 988. [CrossRef]

32. Li, S.; Li, X. Global understanding of farmland abandonment: A review and prospects. J. Geogr. Sci 2017, 27, 1123. [CrossRef]

33. Chen, Y.; Wang, Y.; Fu, B.; Wang, H.W.; Wang, W. Spatial patterns of farmland abandonment and its impact factors in the central three gorges reservoir area . J. Mt. Sci. 2018, 15, 631. [CrossRef]

34. Ruda, G. Rural buildings and environment. Landsc. Urban Plan. 1998, 41, 93-97. [CrossRef]

35. Saganeiti, L.; Favale, A.; Pilogallo, A.; Scorza, F.; Murgante, B. Assessing urban fragmentation at regional scale using sprinkling indexes. Sustainability 2018, 10, 3274. [CrossRef]

36. Statuto, D.; Tortora, A.; Picuno, P. A GIS approach for the quantification of forest and agricultural biomass in the Basilicata region. J. Agric. Eng. 2013, e125, 627-631. [CrossRef]

37. Cillis, G.; Statuto, D.; Picuno, P. Historical maps processed into a GIS for the assessment of forest landscape dynamics. In Proceedings of the Public Recreation and Landscape Protection-With Sense Hand in Hand? Křtiny, Czech Republic, 13-15 May 2019; pp. 180-184. Available online: https://www.researchgate.net/publication/333192060_HISTORICAL_MAPS_PROCESSED_INTO_ A_GIS_FOR_THE_ASSESSMENT_OF_FOREST_LANDSCAPE_DYNAMICS (accessed on 24 August 2019).

38. Grano, M.C. Paesaggio, strutture rurali e architettura popolare nelle province di potenza e matera. In Cultural Landscapes: Metodi, Strumenti e Analisi del Paesaggio fra Archeologia, geologia e Storia in Contesti di Studio del Lazio e Della Basilicata (Italia); Gabrielli, G., Lazzari, M., Sabia, C.A., Del Lungo, S., Eds.; BAR International Series 2629; Archaeopress: Oxford, UK, 2014; pp. 131-148. Available online: https://www.researchgate.net/publication/303932128_PAESAGGIO_STRUTTURE_RURALI_E_ ARCHITETTURA_POPOLARE_NELLE_PROVINCE_DI_POTENZA_E_MATERA (accessed on 24 August 2019).

39. Basilicata Region. Le Trasformazioni dei Paesaggi Agrari in Basilicata-Indirizzi per il Controllo e la Gestione; Basilicata Region: Potenza, Italy, 2007.

40. Franciosa, L. La casa rurale nella Lucania. In The rural house in Lucania Region, in Italian; Ohlski: Firenze, Italy, 1942.

41. Cultural Heritage and Landscape Italian Code, art. 10 Legislative Decree n. 42/2004.

42. Statuto, D.; Picuno, P. Valorisation of vernacular farm buildings for the sustainable development of rural tourism in mountain areas of the Adriatic-Ionian macro-region. J. Agric. Eng. 2017, 48, 21-26. [CrossRef]

43. Cillis, G.; Statuto, D. Landscape protection and tourist valorisation of the cultural and natural heritage of the UNESCO site of Matera (Italy). In Proceedings of the Public Recreation and Landscape Protection-With Nature Hand in Hand? Křtiny, Czech Republic, 2-4 May 2018; pp. 226-231. Available online: https://www.researchgate.net/publication/325093595_Landscape_protection_and_tourist_ valorisation_of_the_cultural_and_natural_heritage_of_the_UNESCO_site_of_Matera_Italy (accessed on 24 August 2019).

44. Geoportale Nazionale. Available online: http://www.pcn.minambiente.it/ (accessed on 27 August 2019). 
45. RSDI-Infrastruttura Regionale dei Dati Spaziali della Regione Basilicata. Available online: https://rsdi. regione.basilicata.it/ (accessed on 29 August 2019).

46. QGIS Development Team. QGIS Geographic Information System. Open Source Geospatial Foundation Project. 2018. Available online: http://qgis.osgeo.org (accessed on 1 August 2019).

47. R Core Team. R: A Language and Environment for Statistical Computing. R Foundation for Statistical Computing, Vienna, Austria. 2014. Available online: http://www.R-project.org/ (accessed on 1 August 2019).

48. QGIS NNJoin Plugin. 2019. Available online: http://arken.nmbu.no/ \{\}havatv/gis/qgisplugins/NNJoin (accessed on 24 August 2019).

49. De Reu, J.; Bourgeois, J.; Bats, M.; Zwertvaegher, A.; Gelorini, V.; De Smedt, P.; Chu, W.; Antrop, M.; De Maeyer, P.; Finke, P.; et al. Application of the topographic position index to heterogeneous landscapes. Geomorphology 2013, 186, 39-49. [CrossRef]

50. Amatulli, G.; Domisch, S.; Tuanmu, M.; Parmentier, B.; Ranipeta, A.; Malczyk, J.; Jetz, W. A suite of global, cross-scale topographic variables for environmental and biodiversity modeling. Sci. Data 2018, 5, 180040. [CrossRef] [PubMed]

51. Weiss, A.D. Topographic Position and Landforms Analysis. In Poster Presentation, ESRI Users Conference. In Poster Presentation, ESRI Users Conference; San Diego, CA, USA, 2001; Available online: http://www. jennessent.com/downloads/tpi-poster-tnc_18x22.pdf (accessed on 24 August 2019).

52. Riley, S.J.; DeGloria, S.D.; Elliot, R. A terrain ruggedness index that quantifies topographic heterogeneity. Intermt. J. Sci. 1999, 5, 23-27.

53. Miller, D. A method for estimating changes in the visibility of land cover. Landsc. Urban Plan. 2001, 54, 9-104. [CrossRef]

54. Sander, H.A.; Manson, S.M. Heights and locations of artificial structures in viewshed calculation: How close is close enough? Landsc. Urban Plan. 2007, 82, 257-270. [CrossRef]

55. Čučković, Z. Advanced viewshed analysis: A Quantum GIS plug-in for the analysis of visual landscapes. J. Open Source Softw. 2016, 1, 32. [CrossRef]

56. Armesto González, J.; Docampo, M.L.G.; Cañas Guerrero, I. The application of new technologies in construction: Inventory and characterisation of rural constructions using the Ikonos satellite image. Build. Environ. 2006, 41, 174-183. [CrossRef]

57. Xu, F.; Ho, H.C.; Chi, G.; Wang, Z. Abandoned rural residential land: Using machine learning techniques to identify rural residential land vulnerable to be abandoned in mountainous areas. Habitat Int. 2019, 84, 43-56. [CrossRef]

58. Terres, J.M.; Nisini Scacchiafichi, L.; Wania, A.; Ambar, M.; Anguiano, E.; Buckwell, A.; Coppola, A.; Gocht, A.; Nordström Källström, H.; Pointereau, P.; et al. Farmland abandonment in Europe: Identification of drivers and indicators, and development of a composite indicator of risk. Land Use Policy 2015, 49, 20-34. [CrossRef]

59. Lasanta, T.; Nadal-Romero, E.; Arnáez, J. Managing abandoned farmland to control the impact of re-vegetation on the environment. The state of the art in Europe. Environ. Sci. Policy 2015, 52, 99-109. [CrossRef]

60. Ustaoglu, E.; Collier, M.J. Farmland abandonment in Europe: An overview of drivers, consequences and assessment of the sustainability implications. Environ. Rev. 2018. [CrossRef]

61. Vidal-Macua, J.J.; Ninyerola, M.; Zabala, A.; Domingo-Marimon, C.; Gonzalez-Guerrero, O.; Pons, X. Environmental and socioeconomic factors of abandonment of rainfed and irrigated crops in northeast Spain. Appl. Geogr. 2018, 90, 155-174. [CrossRef]

62. Statuto, D.; Cillis, G.; Picuno, P. Visual quality indicators for assessing landscape characteristics and managing its protection. In Proceedings of the Public Recreation and Landscape Protection-With Sense Hand in Hand? Křtiny, Czech Republic, 13-15 May 2019; pp. 476-480. Available online: https://www.researchgate.net/publication/333192079_VISUAL_QUALITY_INDICATORS_FOR_ ASSESSING_LANDSCAPE_CHARACTERISTICS_AND_MANAGING_ITS_PROTECTION (accessed on 24 August 2019).

63. Olišarová, L.; Cillis, G.; Statuto, D.; Picuno, P. Analysis of the impact of settlement patterns on landscape protection in two different European rural areas. In Proceedings of the Conference on: Public Recreation and Landscape Protection: With Nature Hand in Hand! Křtiny, Czech Republic, 2-4 May 2018; pp. 34-39. Available online: https://www.researchgate.net/publication/324991304_Analysis_of_the_impact_ of_settlement_patterns_on_landscape_protection_in_two_different_european_rural_areas (accessed on 24 August 2019). 
64. Keenleyside, C.; Tucker, G.M. Farmland abandonment in the EU: An assessment of trends and prospects. In Report Prepared for WWF; Institute for European Environmental Policy: London, UK, 2010.

65. Palmer, J.F. The contribution of a GIS-based landscape assessment model to a scientifically rigorous approach to visual impact assessment. Landsc. Urban Plan. 2019, 189, 80-90. [CrossRef]

66. Picuno, P.; Cillis, G.; Statuto, D. Investigating the time evolution of a rural landscape: How historical maps may provide environmental information when processed using a GIS. Ecol. Eng. 2019, 139, 105580. [CrossRef]

67. Wu, J. Landscape sustainability science: Ecosystem services and human well-being in changing landscapes. Landsc. Ecol. 2013, 28, 999. [CrossRef]

(C) 2019 by the authors. Licensee MDPI, Basel, Switzerland. This article is an open access article distributed under the terms and conditions of the Creative Commons Attribution (CC BY) license (http://creativecommons.org/licenses/by/4.0/). 